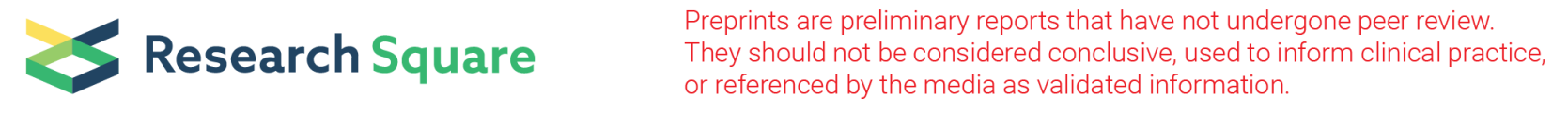

\title{
Development of high strength self-compacted concrete with supplementary cementitious materials
}

Muneeb Ayoub Memon ( $\nabla$ engr.muneebmemon@gmail.com )

: Quaid-e-Awam University of Engineering Science and Technology

Noor Ahmed Memon

: Quaid-e-Awam University of Engineering Science and Technology

Bashir Ahmed Memon

Quaid-e-Awam University of Engineering Science and Technology

\section{Research Article}

Keywords: Self-compacting concrete, Cementitious materials, Filling ability, Passing ability, Segregation resistance, Compressive strength, Spilt tensile strength, Flexural strength

Posted Date: March 7th, 2022

DOI: https://doi.org/10.21203/rs.3.rs-1353145/v1

License: @ (i) This work is licensed under a Creative Commons Attribution 4.0 International License. Read Full License 


\section{Abstract}

Self-compacting concrete (SCC) is the type of concrete that can flow under its own weight and completely fills the formwork without using vibration efforts. Since the manufacturing of cement has negative effects on the environment, the construction industry is putting a lot of effort to explore alternative supplementary cementitious materials (SCMs). This study is aimed to produce highstrength SCC with SCMs i.e., silica fume (SF) and fly ash (FA). The laboratory tests were conducted to determine the fresh and hardened properties of newly produced high strength SCC with binary and ternary use of SF and FA as partial replacement of cement. The replacement levels of cement with SF and FA were 5 to $20 \%$ and 5 to $30 \%$ with $5 \%$ increment by weight of cement, respectively. The results have revealed that both the fresh and hardened properties of SCCs depend on the binary and ternary use of SCMs. Furthermore, a substantial increase in the compressive, spilt tensile and flexural strength was observed for all the mixes of SCC with the addition of SCMs. However, the optimum replacement level of cement for producing high strength SCC was found as $10 \%$ SF and $15 \%$ FA. The resulting green concrete is not only good from strength point of view but also helps to some extent in management of the waste. It also helps in reducing the adverse impacts on environment in general and individuals' health in particular due to reduced waste and reduced production of the ingredients of concrete.

\section{Highlights}

- High-strength self-compacting concrete with supplementary cementitious materials.

- Binary and ternary blending of waste materials for production of self-compacting high strength concrete.

- Fresh properties were slightly affected with the addition of cementitious materials.

- Hardened properties were significantly improved with cementitious materials.

- Reduced adverse effects on environment

- Waste management

\section{Introduction}

Concrete proves itself as a global construction material with its higher compressive strength, extreme durability, and better stiffness, with adaptation in the construction industry at a faster rate. Mostly concrete is manufactured with locally available materials but the existing scientific research focuses on discovering alternative materials from wastes, i.e., the by-product of industries that may cause danger to the surroundings. The demand for construction materials is increasing day by day for infrastructural reasons. Thus, the use of concrete ingredients is also increasing. This can be saved to some extent by using alternative new and easily available materials in concrete mix (Gokulnath et al. 2020).

The applications of concrete in structural elements like slabs, beams, columns, footings, beam-column joints, slab-beam-column joints, etc especially the areas of congested reinforcement need a high degree of compaction efforts particularly in areas of heavy reinforcement without any problem of segregation. Improper compaction/vibration affects the durability and strength characteristics of concrete structures. To avoid the same use of Self Compacting Concrete (SCC) may be the better solution (Vivek et al. 2017). Self-compacting concrete is the type of concrete that can flow under its own weight and completely fill the formwork without using vibration efforts. Its behavior is cohesive enough and does not show any sign of bleeding and segregation at the time of placing (Memon et al. 2018). The high flowability in SCC usually contains a high amount of superplasticizers, a high volume of fines, mineral additives and viscosity modifying agents (VMA). Whilst the use of superplasticizers maintains the fluidity, fines content provides the stability to the mix for avoiding the issues of bleeding and segregation (Mohamed 2011). The use of some mineral admixtures like fly ash (FA) and ground granulated blast furnace slag (GGBFS) in SCC reduces the dosage of superplasticizers due to their greater fineness and maintain the same slump compared to the SCC mixes with Portland cement (PC) (Yahia et al. 1999). It is estimated that as compared to the normally vibrated concrete (NVC) the use of SCC results in $40 \%$ faster construction with significantly more strength, durability and elastic modulus (Perssoiv 1998; Nocher 2001; Persson 2001).

SCC offers various advantages like faster rate of construction, reduction in skilled labor at the site, brilliant surface finishes, easier poring and placing without segregation, improved durability performance, facilitates the choice of section size, easy to pour in heavily reinforced deeper and thinner concrete sections, reduced noise pollution, avoiding vibration equipment at the site, safer working environment, etc. SCC mixes have higher compressive strength than NVC. The gain in compressive strength is about $60 \%$

Page $2 / 24$ 
than that of the normal conventional concrete (Druta 2003). No doubt these characteristics of SCC are due to the lower water binder ratio and presence of superplasticizers that reduce the water demand to a greater extent and also due to the addition of mineral admixtures and a huge amount of filler materials for extreme consistency (Mohamed 2011; Sonebi 2004). SCC has been used in various structural elements like slabs on grade (Groth and Nemegeer 1999), overlays slabs (Carlswärd 2006), pre-cast beams and roof elements (Dhonde et al. 2007), pre-stressed beams (Ferrara and Meda 2006), beam elements with conventional reinforcement (Grunewald 2004), sheet piles (Di Prisco et al. 2006), tunnel linings (Di Prisco et al. 2006), post-tensioning members (Barragán et al. 2004), panels and slabs for housing units (Borralleras et al. 2007; Romano et al. 2007), facade panels (Pereira et al. 2004; Bigas et al. 2007), etc.

Addition of mineral chemical admixtures as partial replacement of cement in mortars and concretes mostly in SCCs improve the workability at fresh state, mechanical and durability characteristics at hardened state due to their pozzolanic and self-compacting effects (Mardani-Aghabaglou et al. 2014). Silica fume (SF) and fly ash (FA) are the most probably used mineral additives in mortars and concretes. Silica fume is used as a partial replacement of cement to produce high-performance concrete (HPC). Due to its reactive pozzolanic properties, the silica fume in concretes results in more discontinues and impermeable pore structures than the plain concretes without SF. The addition of SF in concrete mixes enhances the rate of hydration at an early age due to releasing of OH ions and alkalis into pore fluids (Mardani-Aghabaglou et al. 2014; Zhu et al. 2013; Felekoğlu et al. 2006). Also, fly ash has very optimistic effects on concretes as it lowers the water demand, reduces the heat of hydration, bleeding and segregation issues in obtaining satisfactory durability performance (Wang et al. 2012). Moreover, the advantages of using these mineral additives in concretes are reducing environmental hazards, producing sustainable concretes thus resulting in the economy. The combined use of silica fume and fly ash in ternary mixes becomes more beneficial due to effective pozzolanic reactions. At the same time, SF reduces excessive bleeding while the fly ash increases the workability and improves long-term serviceability (Bagheri et al. 2013).

The chemical additives superplasticizers, filler materials and viscosity modifying agents reduce the water demand at a high level in the production of SCCs (Mohamed 2011; Memon et al. 2020; Silva and Brito 2015). These chemicals play important role in producing more sustainable and durable SCC (Mohamed 2011; Yahia et al. 1999). Nowadays, the use of supplementary cementitious materials (SCMs) such as, fly ash, silica fume, slags in SCCs not only reduces the cost of construction but improves the mechanical and durability performance both at fresh and hardened state (Sasanipour and Aslani 2019). The addition of SCMs helped to produce high volume calcium silicate hydrate gel, thus, the formation of dense gel improves the bond between paste and aggregates (Verian et al. 2018; Kapoor et al. 2016; Mastali and Dalvand 2016).

Fly ash is generally named Pulverized fuel ash in the United Kingdom. Due to its pozzolanic properties, it is most commonly used as cement replacement material in the construction industry (Razak and Wong 2005). Silica fume; also called micro silica; was first disclosed in Norway in 1947. It contains a quantum of silicon dioxides. Due to the well-known pozzolanic properties of silicon dioxides, many studies have been published on its use (Khayat and Mitchell 2009). Silica fume is composed of very finer particles approximately six-time smaller than the particles of cement. Hence it has been found that when silica fume is added with cement in concretes reduces the minute pore spaces (Bhanja and Sengupta 2005).

SCC offers similar physical, mechanical and durability properties to that of NVC. As from the name self-compacting concrete reflects some more special flow properties i-e filling ability, passing ability and segregation resistance. The filling ability is the capacity of concrete to flow under its own weight and fill the formwork completely without the use of vibrators. The passing ability of concrete is used to pass the concrete from narrow spaces of reinforcement and maintain consistency. The segregation resistance of the mix of concrete is to avoid the setting of concrete during the flow of self-compacting concrete. The main durability characteristics of SCC are water absorption and oxygen permeability. SCC has more chances of bleeding due to the excessive use of superplasticizers, but the fillers and cementitious materials in SCC lower down the rate of bleeding and give moderate viscous flow resulting in low oxygen permeability. Due to less air content in SCC, it makes structures free from honeycombing problems (Gokulnath et al. 2020).

Many experimental studies have been undertaken by numerous researchers since a long time on the various properties of selfcompacted concrete with various cement replacement materials in order to evaluate the fresh, mechanical and durability characteristics of self-compacted concrete. Sasanipour et al. (2019) studied the effect of silica fume on durability characteristics of SCC made with recycled coarse aggregates. They used silica fume as a binder at $8 \%$ of cement. The Recycled Coarse Aggregates (RCA) were partially replaced at $25 \%, 50 \%, 75 \%$ and $100 \%$ by crushed coarse aggregates with and without silica fume in SCC. Fresh 
properties, as well as compressive strength by UPV, Water Absorption (WA), Electrical Resistivity (ER) and chloride ion penetration tests, were conducted for hardened concrete. It was found that the incorporation of silica fume in SCC increases the workability performance. Also, the authors observed higher electrical resistivity compared to other mixes. Pulse velocity slightly reduced due to porosity in RCA but the reduction is very meager and may be ignored. Benaicha et. al (2015) investigated the mechanical and rheological properties of SCC with silica fume and viscosity modifying agents. SF was replaced by cement at 0 to $30 \%$ with a $5 \%$ increment while VMA was used from 0.05 to $0.3 \%$ with a $0.05 \%$ increment. From the results, it was observed that both the SF and VMA in SCC improve the stability and robustness of concrete. Furthermore, it was noticed that silica fume has some viscosity modifying properties and can replace VMA and vice versa. Memon et al. (2020) discussed the effect of fly ash and uncrushed coarse aggregates in the production of SCC. The fly ash was replaced by cement from $0-20 \%$ with a $4 \%$ increment. Twelve SCC mixes were designed six for each crushed and uncrushed coarse aggregates. The fresh properties were evaluated by slump flow, $\mathrm{V}$ funnel, J-ring and L-box tests. While the compressive strength at 7, 14 and 28 days was determined at hardened state. The results revealed that the fresh properties of all the mixes are within the limits proposed by EFNARC. The compressive strength of SCC depends on the dosage of fly ash. Compressive strength for SCC with crushed CA was better than obtained in the case of uncrushed coarse aggregates. Ponikiewski and Gołaszewski (2013) used high calcium fly ash (HCFA) along with other chemical additives in SCC. HCFA was used as 10, 20 and $30 \%$ by weight of cement. The outcomes showed that the presence of HCFA retards the flow of concrete with a little amount of superplasticizer. However, with treatment or by grinding the HCFA better performance in terms of flow and resistance to segregation may be achieved.

Also, various studies have been conducted on the binary and ternary uses of pozzolanic materials to enhance the properties of concrete. Thomas et al. (1999) discussed the effect of combined use of SF and FA on durability and strength characteristics of concrete. It was concluded that ternary blends cement with SF and FA offers significant benefits over the binary blends cement with SF and FA. Gesoglu and Ozbay (2007) investigated the fresh and hardened properties of SCC with binary, ternary and quaternary use of FA, SF and Slag. It was reported that the ternary blended mixes with SF and FA showed the maximum compressive strength than the binary blended and quaternary mixes at the same replacement levels. Also, Guneyisi et al. (2010) reported the strength and drying shrinkage behavior of SCC with combined uses of SF and FA. It is concluded that the mixes with ternary blends $(P C+S F+F A)$ offer higher compressive strength than the binary blends both the (PC + SF) and (PC + FA) with the same amount of replacement. Nochaiya et al. (2010) reported that combined use of SF and FA sowed a higher compressive strength at early ages. Benli et al. (2017) conducted an experimental study to investigate the fresh, hardened and sorptivity characteristics of binary and ternary blended self-compacted concrete with silica fume and fly ash at different curing days \& regimes. Tap water curing (WC), wet sack curing (WSC), air curing (AC), and liquid paraffin wax curing (LPWC) and different curing ages $(3,7,28,56$ and 180 days) were adopted. Slump flow and V-funnel time were recorded for filling ability of SCC at fresh state, while, for hardened properties compressive, flexural strength and sorptivity tests were performed. From results, it was observed that binary mix with $10 \%$ fly ash, ternary mix with $10 \%$ fly ash and $6 \%$ silica fume at 180 days cured with wet sack yielded the foremost results of compressive strength. Maximum flexural strength was recorded at 180 days LPWC curing for control and 10\% silica fume mixes. Furthermore, it was also noted that the $10 \%$ SF mix has the lowest sorptivity co-efficient with a W/B ratio of 0.4 among all the mixes. Wongkeo et al. (2014) studied the compressive strength and chloride resistance of SCC manufactured with a high percentage of fly ash (FA) and silica fume (SF). Authors asserted that the SCC with binary blended with high-level FA generally has reduced compressive strength at all curing ages. However ternary blending increases compressive strength after 7 days when compared to binary mixes. A maximum of $60 \mathrm{MPa}$ compressive strength was observed for a ternary mix containing both the SF and FA. Furthermore, the charge passed for assessing chloride resistance decreases with the addition of FA dosage although the volume of permeable pore space (voids) and water absorption of SCC were increased. Mohamed (2011) discussed the compressive strength of SCC with binary and ternary use of SF and FA under different curing conditions in their research article. Fly ash (10 to 50\%) and silica fume (10 to $20 \%)$ with $5 \%$ increment were used as partial replacement of cement. The slump flow test and V-funnel test were carried out for showing flowability. Results showed that $15 \%$ of SF gives higher values of compressive strength than those with $30 \%$ of FA and water curing for 28 days gives better compressive strength than other modes of curing. Dehwah (2012) used quarry dust powder (QDP), silica fume (SF), or fly ash (FA) as partial replacement of cement in SCC. Slump flow time, V-funnel time, L-box and U-box tests were performed at fresh state while compressive, tensile, UPV and flexural strength were determined at hardened state. The results of mechanical properties indicated that SCC with QDP (8-10\%) yields better performance than SCC with individual SF and FA. Furthermore, a few researchers discussed the effect of ternary use of SF and FA and reported the enhancement in compressive strength (Khatri et al. 1995; Mehta and Gjorv 1982; Ozyildirim and Halstead 1994), alkali-silica reaction (Thomas et al. 1999; Lane 
and Ozyildirim 1999), resistance to sulphate attacks (Thomas et al. 1999) and decrease in the pore size distribution (Mehta and Gjorv 1982) and chloride permeability (Ozyildirim and Halstead 1994; Thomas et al. 1999)

The above discussion of the available state of art indicates that a good number of investigations conducted by the various researchers in the area of SCC have been conducted including the research on the effect of supplementary materials. However, it is worth noting that the scope of these studies has been very limited with wide variation in the results. Thus, a systematic and broadbased study is essential to arrive at the logical conclusion which may be the benchmark for not only the future researchers but also to serve as a guideline for the construction industry and end-users to adopt SCC with more confidence at mass scale. Hence in this research program, an experimental study is carried out to develop the high-strength self-compacting concrete with binary and ternary use of silica fume and fly ash as supplementary cementitious materials.

\subsection{Significance of the study}

The outcome of the proposed study is self-compacting high strength concrete with the binary and ternary blending of waste cementitious materials. The final product is useful for concrete in narrow and congested sections. As it is using the waste materials in concrete, therefore, helps in reduced waste management to some extent. It also helps in reduced production of cement which in turn helps in the reduction of the hazardous effects due to the production of cement. In turn, it also reduces the associated health issues of the individual. The product also helps the industry with alternative materials of conventional concrete.

\section{Materials And Mixes}

In this study, a total of 35 mixes were developed. Out of these mixes, one mix was made with Portland cement only and called control mix to check the results of the proposed concrete mixes. Ten concrete mixes were binarily blended having the combination of two of the three binders (OPC, SF and FA) with different dosages. Whereas, rest of the 24 concrete mixes were ternary blended having OPC, SF and FA with the variation of the dosage. Fixed water to binder ratio equal to 0.34 and $500 \mathrm{~kg} / \mathrm{m}^{3}$ binder content was used throughout the study. The water content is adjusted with the appropriate dosage of the superplasticizer. A maximum size of 20 $\mathrm{mm}$ coarse aggregates is used. The volume of coarse aggregates adopted is $35 \%$ of the total volume of concrete. The sand passed from the \#4 sieve is used for balancing the other constituents in the volume of concrete. Table 1 shows the gradation of fine and coarse aggregates. The dosages of SF and FA vary from $5-20 \%$ and $5-30 \%$ respectively with a $5 \%$ increment in both cases. The SCMs are used individually as well as combined to produce binary and ternary blends of SCC. The fresh properties: slump flow time and diameter, V-funnel time, J-ring height, L-box height ratio, V-funnel time at 5 minutes were investigated as per the guidelines of (EFNARC 2002). The strength properties investigated are compressive, spilt tensile, flexural strength. Table. 2 presents the details of concrete mixes used in this research work along with quantities of ingredients for one cubic meter of concrete. 
Table 1

Gradation of coarse and fine aggregates

\begin{tabular}{|lll|}
\hline sieve size $(\mathrm{mm})$ & Fine Aggregates & Coarse Aggregates \\
\cline { 2 - 3 } & Passing (\%) & Passing (\%) \\
\hline 14 & 100 & 100 \\
\hline 13.2 & 100 & 95.43 \\
\hline 12.5 & 100 & 83.4 \\
\hline 9.5 & 100 & 46.1 \\
\hline 4.75 & 99.8 & 0.35 \\
\hline 2.36 & 83.96 & 0 \\
\hline 1.18 & 66.42 & 0 \\
\hline 0.6 & 54.1 & 0 \\
\hline 0.3 & 38.1 & 0 \\
\hline 1.15 & 9.1 & 0 \\
\hline pan & 0 & 0 \\
\hline
\end{tabular}


Table 2

Details of mixes and quantities of ingredients for $1 \mathrm{~m}^{3}$ of concrete

\begin{tabular}{|c|c|c|c|c|c|c|c|c|c|c|c|}
\hline $\begin{array}{l}\text { Mix } \\
\text { ID }\end{array}$ & $\begin{array}{l}\text { Mix } \\
\text { description }\end{array}$ & $\begin{array}{l}\text { Mix } \\
\text { blends }\end{array}$ & W/B & $\begin{array}{l}\text { SP } \\
(\%)\end{array}$ & $\begin{array}{l}\mathrm{FA} \\
\mathrm{kg} / \mathrm{m}^{3}\end{array}$ & $\begin{array}{l}\mathrm{CA} \\
\mathrm{kg} / \mathrm{m}^{3}\end{array}$ & $\begin{array}{l}\text { Water } \\
\mathrm{kg} / \mathrm{m}^{3}\end{array}$ & $\begin{array}{l}\mathrm{PC} \\
\mathrm{kg} / \mathrm{m}^{3}\end{array}$ & $\begin{array}{l}\text { Fly ash } \\
\mathrm{kg} / \mathrm{m}^{3}\end{array}$ & $\begin{array}{l}\text { Silica Fume } \\
\mathrm{kg} / \mathrm{m}^{3}\end{array}$ & $\begin{array}{l}\text { Binder } \\
\mathrm{kg} / \mathrm{m}^{3}\end{array}$ \\
\hline M1 & PC & Control & 0.34 & 2.0 & 870 & 880 & 187 & 550.0 & 0.0 & 0.0 & 550 \\
\hline M2 & $5 \mathrm{FA}$ & Binary & 0.34 & 2.0 & 870 & 880 & 187 & 522.5 & 27.5 & 0.0 & 550 \\
\hline M3 & $10 \mathrm{FA}$ & Binary & 0.34 & 2.0 & 870 & 880 & 187 & 495.0 & 55.0 & 0.0 & 550 \\
\hline M4 & $15 \mathrm{FA}$ & Binary & 0.34 & 2.0 & 870 & 880 & 187 & 467.5 & 82.5 & 0.0 & 550 \\
\hline M5 & $20 \mathrm{FA}$ & Binary & 0.34 & 2.0 & 870 & 880 & 187 & 440.0 & 110.0 & 0.0 & 550 \\
\hline M6 & $25 \mathrm{FA}$ & Binary & 0.34 & 1.5 & 870 & 880 & 187 & 412.5 & 137.5 & 0.0 & 550 \\
\hline M7 & $30 \mathrm{FA}$ & Binary & 0.34 & 1.0 & 870 & 880 & 187 & 385.0 & 165.0 & 0.0 & 550 \\
\hline M8 & $5 \mathrm{SF}$ & Binary & 0.34 & 2.5 & 870 & 880 & 187 & 522.5 & 0.0 & 27.5 & 550 \\
\hline M9 & $10 \mathrm{SF}$ & Binary & 0.34 & 3.0 & 870 & 880 & 187 & 495.0 & 0.0 & 55.0 & 550 \\
\hline M10 & $15 \mathrm{SF}$ & Binary & 0.34 & 3.5 & 870 & 880 & 187 & 467.5 & 0.0 & 82.5 & 550 \\
\hline M11 & $20 \mathrm{SF}$ & Binary & 0.34 & 4.5 & 870 & 880 & 187 & 440.0 & 0.0 & 110 & 550 \\
\hline M12 & 5 SF 5 FA & Ternary & 0.34 & 2.25 & 870 & 880 & 187 & 495.0 & 27.5 & 27.5 & 550 \\
\hline M13 & 5 SF 10 FA & Ternary & 0.34 & 2.25 & 870 & 880 & 187 & 467.5 & 55.0 & 27.5 & 550 \\
\hline M14 & $5 \mathrm{SF} 15 \mathrm{FA}$ & Ternary & 0.34 & 2.25 & 870 & 880 & 187 & 440.0 & 82.5 & 27.5 & 550 \\
\hline M15 & $5 \mathrm{SF} 20 \mathrm{FA}$ & Ternary & 0.34 & 2.25 & 870 & 880 & 187 & 412.5 & 110.0 & 27.5 & 550 \\
\hline M16 & $5 \mathrm{SF} 25 \mathrm{FA}$ & Ternary & 0.34 & 2.0 & 870 & 880 & 187 & 385.0 & 137.5 & 27.5 & 550 \\
\hline M17 & $5 \mathrm{SF} 30 \mathrm{FA}$ & Ternary & 0.34 & 1.75 & 870 & 880 & 187 & 357.5 & 165.0 & 27.5 & 550 \\
\hline M18 & 10 SF 5 FA & Ternary & 0.34 & 2.75 & 870 & 880 & 187 & 467.5 & 27.5 & 55.0 & 550 \\
\hline M19 & $\begin{array}{l}10 \text { SF } 10 \\
\text { FA }\end{array}$ & Ternary & 0.34 & 2.75 & 870 & 880 & 187 & 440.0 & 55.0 & 55.0 & 550 \\
\hline M20 & $\begin{array}{l}10 \text { SF } 15 \\
\text { FA }\end{array}$ & Ternary & 0.34 & 2.5 & 870 & 880 & 187 & 412.5 & 82.5 & 55.0 & 550 \\
\hline M21 & $\begin{array}{l}10 \text { SF } 20 \\
\text { FA }\end{array}$ & Ternary & 0.34 & 2.5 & 870 & 880 & 187 & 385.0 & 110.0 & 55.0 & 550 \\
\hline M22 & $\begin{array}{l}10 \text { SF } 25 \\
\text { FA }\end{array}$ & Ternary & 0.34 & 2.25 & 870 & 880 & 187 & 357.5 & 137.5 & 55.0 & 550 \\
\hline M23 & $\begin{array}{l}10 \text { SF } 30 \\
\text { FA }\end{array}$ & Ternary & 0.34 & 2.25 & 870 & 880 & 187 & 330.0 & 165.0 & 55.0 & 550 \\
\hline M24 & 15 SF 5 FA & Ternary & 0.34 & 3.5 & 870 & 880 & 187 & 440.0 & 27.5 & 82.5 & 550 \\
\hline M25 & $\begin{array}{l}15 \text { SF } 10 \\
\text { FA }\end{array}$ & Ternary & 0.34 & 3.5 & 870 & 880 & 187 & 412.5 & 55.0 & 82.5 & 550 \\
\hline M26 & $\begin{array}{l}15 \text { SF } 15 \\
\text { FA }\end{array}$ & Ternary & 0.34 & 3.5 & 870 & 880 & 187 & 385.0 & 82.5 & 82.5 & 550 \\
\hline M27 & $\begin{array}{l}15 \text { SF } 20 \\
\text { FA }\end{array}$ & Ternary & 0.34 & 3.0 & 870 & 880 & 187 & 357.5 & 110.0 & 82.5 & 550 \\
\hline M28 & $\begin{array}{l}15 \text { SF } 25 \\
\text { FA }\end{array}$ & Ternary & 0.34 & 2.75 & 870 & 880 & 187 & 330.0 & 137.5 & 82.5 & 550 \\
\hline
\end{tabular}




\begin{tabular}{|c|c|c|c|c|c|c|c|c|c|c|c|}
\hline $\begin{array}{l}\text { Mix } \\
\text { ID }\end{array}$ & $\begin{array}{l}\text { Mix } \\
\text { description }\end{array}$ & $\begin{array}{l}\text { Mix } \\
\text { blends }\end{array}$ & W/B & $\begin{array}{l}\text { SP } \\
(\%)\end{array}$ & $\begin{array}{l}\mathrm{FA} \\
\mathrm{kg} / \mathrm{m}^{3}\end{array}$ & $\begin{array}{l}\mathrm{CA} \\
\mathrm{kg} / \mathrm{m}^{3}\end{array}$ & $\begin{array}{l}\text { Water } \\
\mathrm{kg} / \mathrm{m}^{3}\end{array}$ & $\begin{array}{l}\mathrm{PC} \\
\mathrm{kg} / \mathrm{m}^{3}\end{array}$ & $\begin{array}{l}\text { Fly ash } \\
\mathrm{kg} / \mathrm{m}^{3}\end{array}$ & $\begin{array}{l}\text { Silica Fume } \\
\mathrm{kg} / \mathrm{m}^{3}\end{array}$ & $\begin{array}{l}\text { Binder } \\
\mathrm{kg} / \mathrm{m}^{3}\end{array}$ \\
\hline M29 & $\begin{array}{l}15 \text { SF } 30 \\
\text { FA }\end{array}$ & Ternary & 0.34 & 2.5 & 870 & 880 & 187 & 302.5 & 165.0 & 82.5 & 550 \\
\hline M30 & 20 SF 5 FA & Ternary & 0.34 & 4.5 & 870 & 880 & 187 & 412.5 & 27.5 & 110.0 & 550 \\
\hline M31 & $\begin{array}{l}20 \text { SF } 10 \\
\text { FA }\end{array}$ & Ternary & 0.34 & 4.5 & 870 & 880 & 187 & 385.0 & 55.0 & 110.0 & 550 \\
\hline M32 & $\begin{array}{l}20 \text { SF } 15 \\
\text { FA }\end{array}$ & Ternary & 0.34 & 4.5 & 870 & 880 & 187 & 357.5 & 82.5 & 110.0 & 550 \\
\hline M33 & $\begin{array}{l}20 \text { SF } 20 \\
\text { FA }\end{array}$ & Ternary & 0.34 & 4.0 & 870 & 880 & 187 & 330.0 & 110.0 & 110.0 & 550 \\
\hline M34 & $\begin{array}{l}20 \text { SF } 25 \\
\text { FA }\end{array}$ & Ternary & 0.34 & 3.75 & 870 & 880 & 187 & 302.5 & 137.5 & 110.0 & 550 \\
\hline M35 & $\begin{array}{l}20 \text { SF } 30 \\
\text { FA }\end{array}$ & Ternary & 0.34 & 3.5 & 870 & 880 & 187 & 275.0 & 165.0 & 110.0 & 550 \\
\hline
\end{tabular}

Locally available ordinary Portland cement OPC under the brand name "LUCKY STAR" is used in this research program. The cement conforms to ASTM C150M-18 (2019), possesses 99\% fineness, 3.13 specific gravity, initial and final setting time equal to 65 and 370 minutes respectively. Silica fume with an average particle size of $0.15 \mu \mathrm{m}$ and specific gravity of 2.27 conforming to ASTM C 1240-15 (2019) is used. Class F fly ash used in this research work is obtained from the "Thar Coal" electricity-generating power station. It conforms to ASTM C $618-17$ (2019) and possesses a 2.3 relative density. Tables 3 and 4 show the chemical composition and sieve analysis of cementitious materials. Figure 1 represents the gradation curves of cement, silica fume and fly ash.

Table 3

Chemical composition of cementitious materials

\begin{tabular}{|llll|}
\hline Chemical analysis (\%) & Cement & Silica fume & Fly ash \\
\hline $\mathrm{SiO}_{2}$ & 20.1 & 95.38 & 59.98 \\
\hline $\mathrm{Al}_{2} \mathrm{O}_{3}$ & 7.27 & 1.095 & 27.94 \\
\hline $\mathrm{MgO}$ & 3.089 & 1.10 & 0.945 \\
\hline $\mathrm{CaO}$ & 60.59 & 1.665 & 2.994 \\
\hline $\mathrm{Fe}_{2} \mathrm{O}_{3}$ & 4.003 & 0.5 & 4.07 \\
\hline $\mathrm{K}_{2} \mathrm{O}$ & 1.421 & 0.1 & 1.84 \\
\hline $\mathrm{SO}_{3}$ & 3.495 & 0.15 & - \\
\hline $\mathrm{TiO}_{2}$ & - & - & 2.185 \\
\hline
\end{tabular}


Table 4

Sieve analysis of Cement, Silica fume and Fly ash

\begin{tabular}{|llll|}
\hline Sieve \# & Cement & Fly ash & Silica Fume \\
\cline { 2 - 4 } & Passing (\%) & Passing (\%) & Passing (\%) \\
\hline 40 & 100 & 98 & 78 \\
\hline 50 & 97.67 & 84.33 & 63.33 \\
\hline 100 & 94.33 & 28.33 & 29 \\
\hline 140 & 64.33 & 8.33 & 17.67 \\
\hline 170 & 32.67 & 3.33 & 12 \\
\hline 200 & 16.67 & 2.33 & 8 \\
\hline Pan & - & - & - \\
\hline
\end{tabular}

In this study, a poly-carboxylic acid-based high range water reducing admixture is used. It was in liquid form commercially available under the brand name "Master Polyheed 996" complying with "Type-F" as per ASTM C 494 (2019).

\section{Results And Discussions}

The tests performed on the proposed material and the obtained results are analysed and discussed in the following subsections.

\subsection{Fresh properties}

Generally, the SCC mix of required performance is proportioned in light of specification \& guidelines of SCC following EFNARC (2005). However, the EFNARC guidelines advise the systematic laboratory trial mixes procedure to verify and check the desired performance of SCC. As it is well recognized that SP is added in SCC to achieve required workability. Therefore, it was necessary to get the optimized dosage of SP in the selected mixes. For this purpose, slump flow time $\left(T_{50 \mathrm{~cm}}\right)$ tests were conducted to get an optimized dosage of SP from trial batches for each mix. The obtained results are tabulated in Table 5. It is observed that the workability of SCCs increases with an increase in the dosage of SP. A similar trend was observed for all mixes; binary and ternary blends and control mix. It may also be observed from Table 5 that the demand of SP is fluctuating for both the cementitious materials being used as binary and ternary mixtures to achieve the targeted slump flow time. The obtained results are in good agreement with the test results published by (Mastali and Dalvand 2016). On the other hand, it is further observed that the inclusion of fly ash in the binary and ternary mixes, decreased the demand for superplasticizers remarkably. This may be attributed to the fineness of the fly ash which is finer than the cement. Also, particles of fly ash are round and glassy and they produce a ball-bearing effect during the mixing of the ingredients in a fresh state of the mix resulting in the enhanced flowability of concrete (Deo and Pofale 2015). 
Table 5

Dosage of Superplasticizer $v / \mathrm{s} T_{50 \mathrm{~cm}}$ time

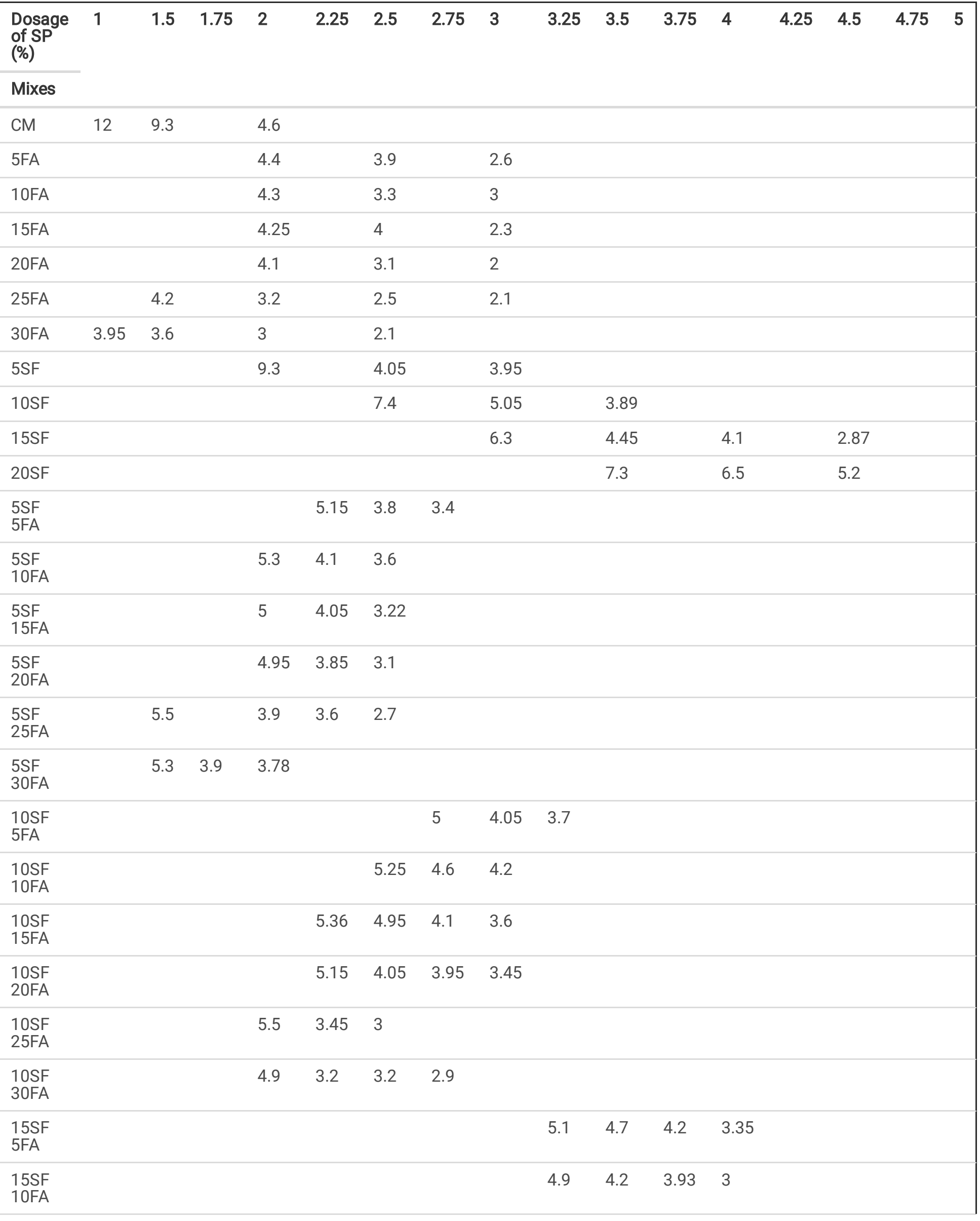




\begin{tabular}{|c|c|c|c|c|c|c|c|c|c|c|c|c|c|c|c|}
\hline $\begin{array}{l}\text { Dosage } \\
\text { of SP } \\
\text { (\%) }\end{array}$ & 1 & 1.5 & 1.75 & 2 & 2.25 & 2.5 & 2.75 & 3 & 3.25 & 3.5 & 3.75 & 4 & 4.25 & 4.5 & \multirow[t]{2}{*}{4.75} \\
\hline Mixes & & & & & & & & & & & & & & & \\
\hline $\begin{array}{l}15 \mathrm{SF} \\
15 \mathrm{FA}\end{array}$ & & & & & & & & & 4.75 & 3.65 & 3.48 & 2.82 & & & \\
\hline $\begin{array}{l}15 \mathrm{SF} \\
20 \mathrm{FA}\end{array}$ & & & & & & & 4.9 & 4.1 & 3.8 & & & & & & \\
\hline $\begin{array}{l}15 \mathrm{SF} \\
25 \mathrm{FA}\end{array}$ & & & & & & 5.1 & 3.75 & 3.6 & & & & & & & \\
\hline $\begin{array}{l}15 \mathrm{SF} \\
30 \mathrm{FA}\end{array}$ & & & & & 4.94 & 3.9 & 3.52 & & & & & & & & \\
\hline $\begin{array}{l}20 \mathrm{SF} \\
5 \mathrm{FA}\end{array}$ & & & & & & & & & & & & & 6.25 & 4.7 & 3.95 \\
\hline $\begin{array}{l}20 \mathrm{SF} \\
\text { 10FA }\end{array}$ & & & & & & & & & & & & & 5.87 & 4.15 & 3.65 \\
\hline $\begin{array}{l}20 \mathrm{SF} \\
15 \mathrm{FA}\end{array}$ & & & & & & & & & & & & & 4.98 & 3.65 & 3.22 \\
\hline $\begin{array}{l}\text { 20SF } \\
20 \mathrm{FA}\end{array}$ & & & & & & & & & & & 6.97 & 4.35 & 4.65 & & \\
\hline $\begin{array}{l}20 \mathrm{SF} \\
25 \mathrm{FA}\end{array}$ & & & & & & & & & & 7.24 & 5.05 & 4.62 & & & \\
\hline $\begin{array}{l}\text { 20SF } \\
30 \mathrm{FA}\end{array}$ & & & & & & & & & 7.82 & 4.9 & 4.05 & & & & \\
\hline
\end{tabular}

\subsubsection{Filling ability of SCC with cementitious materials}

Slump flow diameter and V-funnel tests to access the filling ability of proposed self-compacted concrete are carried out following the standard procedure of the tests. Both of the tests for slump diameter and V-funnel are shown in Fig. 2.

The variation of slump flow time and viscosity classes of all the concrete mixes including controlled mix is shown in Fig. 3 . This figure subplot (a) shows the controlled mix and binary blended mixes with variations of dosage of both the silica fume and fly ash. While subplot (b) and subplot (c) show the same parameter for ternary blended mixes using both silica fume and fly ash. The inclusion of FA in binary blended mixes lowers down the $T_{50}$ time. The flow time for binary blended mixes with $S F$ increased with increasing the SF replacement especially at $20 \%$ dose of SF by weight of cement. However, the $T_{50}$ of ternary mixes blended with SF and FA slightly decreased compared to binary mixes with only SF. Moreover, the $T_{50}$ of ternary mixes increases with increasing the dosages of FA. From Fig. 3 it may also be observed that mixes with $20 \%$ SF and $10 \%$ SF $+30 \%$ FA possess the maximum and minimum $T_{50 \mathrm{~cm}}$ time respectively. It can also be seen from the Fig. 3 , that the slump flow durations of all concrete mixes with the optimized dosages of SP were within the required range of EFNARC (2002) which are in the agreement with the results already reported in the literature by (Choudhary, Gupta \& Nagar, 2020). It was also noted that all the mixes including the controlled mix fall in viscosity class VF2 and such concretes help to enhance segregation resistance and reduce the pressure on the formwork as reported by (Bayasi and Zeng, 1993).

Slump flow values describe the flow-ability of fresh concrete under unconfined conditions. It is a measure of the average diameter of the spreading of concrete after raising the cone. Figure 4 shows the variation of slump flow diameter of all concrete mixes including the controlled mix. The average slump flow diameter of controlled concrete without cementitious materials is $74.625 \mathrm{~cm}$. In binary blended mixes, FA increases the flow diameter while SF decreases it. The lowest observed value of flow diameter is recorded for mix with $20 \%$ SF. In ternary mixes, the flow diameter increased with an increase in the FA replacement. The maximum diameter observed for the mix with $10 \% \mathrm{SF}+30 \% \mathrm{FA}$. For reference, the flow classes are also included in the Fig. 4 . Test results indicate that the slump flow diameter for all the mixes is within the range of 65-80 cm (EFNARC, 2002). It was seen that most of the mixtures confirmed SF2 class $(650-75 \mathrm{~cm})$, which is suitable for many normal applications like walls and columns etc. While some mixtures having a 
greater dosage of fly ash conformed to SF3 in terms of slump flow according to the EFNARC (2002), which is suitable for vertical applications with congested reinforcement.

The results of the V-funnel flow time for all mixes proposed in this research work are shown in Fig. 5. Subplot (a) in this figure shows the recorded parameter when silica fume and fly ash are used individually in the mixes. Subplot (b) gives the details of the parameter for concrete mixes containing fly ash with $5 \%$ and $10 \%$ dosage of the silica fume. Whereas subplot (c) shows the results for the concrete mixes containing fly ash with $15 \%$ and $20 \%$ dosage of silica fume. From these plots, it may be observed that the Vfunnel flow time varies between 9.65 and $19 \mathrm{sec}$. It can be seen that all the mixes meet the requirements of allowable flow time. The minimum flow time is recorded for the mix containing $20 \%$ fly ash, while the maximum is for the mix containing $20 \%$ SF. With the increase in silica fume content, the fluidity of concrete decreases. Consequently, the $\mathrm{V}$-funnel flow time increases. The same reasons and mechanisms were mentioned for slump flow test results. Figure 5 also demonstrates that all of the mixtures were classified as VF2 in terms of viscosity according to EFNARC (2002).

\subsubsection{Passing ability of SCC with cementitious materials}

Passing ability is one of the important properties of self-compacting concrete, which verifies the concrete flowing capacity over the formwork, by passing through the concrete reinforcement without segregation or outflow obstruction occurrence. The selfcompacting concrete passing ability is test verified through the L-box test, $\mathrm{J}$ ring test, and U-Box test. If the concrete does not possess the adequate passing ability, coarse aggregates will cause blockage between the reinforcing bars and resulting in a nonuniform structure. The above-mentioned tests are conducted for all proposed mixes and are shown in Fig. 6. The obtained results of J-ring height are displayed in Fig. 7. The subplots of the figure show similar dosages as explained in the previous section. It may be observed that the obtained results of J-ring height are in accordance with the recommendations by EFNARC (2002). The J-ring height for the controlled mix is recorded equal to 9.6 while the maximum was recorded for the mix with $30 \%$ FA. The test results showed that the J-ring height for all the mixes ranged from 9 to $10 \mathrm{~mm}$, which is a required range of EFNARC (2002).

Another important test of self-compacting concrete to access the fluidity is the L-box test. The same is conducted for the proposed mixes following the standard procedure of the test. The range of the L-box height ratio reported is between 0.8 and 1.0 (ENNARC 2005), whereas, for perfect fluid behavior of self-compacting concrete, the L-box height ratio value is 1.0. Figure 8 shows a pictorial view of the L-box test. The obtained results from the proposed mixes are displayed in Fig. 9. It is observed that all mixtures satisfy the EFNARC limitation for the given L-box height ratio. The L-box height ratio value for the controlled mixture is recorded equal to 0.89. It is observed that the value gradually increased with the more replacement of FA. It was further observed that all the mixes pass through the bars of the L-box very easily and no blockage is seen in any of the mixes. The results of the L-box test show that, although the blocking ratio $\left(\mathrm{H}_{2} / \mathrm{H}_{1}\right)$ gradually decreases with the increase in the quantity of silica fume, the ratio $\left(\mathrm{H}_{2} / \mathrm{H}_{1}\right)$ for all the mixes is above 0.8, which is as per EFNARC (2002) standards. It can also be seen from Fig. 9 that most of the mixes lie on passing ability class PA2, which is suitable for all civil engineering structures.

\subsubsection{Segregation resistance of SCC with Cementitious materials}

In SCC the resistance against segregation is fundamental for homogeneity and quality of the concrete. It mostly suffers from segregation while placing or pouring into the tall and thin sections, which leads to construction defects like cracks or a weak surface. The resistance against segregation becomes an important parameter for the concretes having high slump flow and lower viscosity. The ability of SCC to remain homogeneous in composition during transport and placing was inspected through the VFunnel test at $5 \mathrm{~min}$. Figure 10 shows the results obtained for variations of $\mathrm{V}$-funnel time at $5 \mathrm{~min}$ for all the mixes. According to the results, the V-funnel flow time at 5 min varies between $14.4 \mathrm{sec}$ and $24.8 \mathrm{sec}$. The minimum flow time is recorded for the mix containing $5 \%$ silica fume and $20 \%$ fly ash, while the maximum is recorded for the $20 \mathrm{SF}$ mix. It is also observed that the increase in the content of silica fume decreases fluidity. Consequently, the funnel time increases. The same reasons were discussed in the case of slump flow time also. It was observed that $\mathrm{V}$-funnel flow time at $5 \mathrm{~min}$ for all the mixes was in the required range (i-e $\mathrm{V}$-funnel time +3 sec) according to EFNARC (2002) guidelines.

\subsection{Hardened Properties of SCC with cementitious materials}

In this study total of five specimens of standard size for each test and proposed mix were cast and tested. For the casting of the specimen weight batching was employed. Steel moulds were used for the casting of specimens. Moulds were oiled before pouring the concrete so that the stripping of mould should be easy. The casting was done in accordance with the standard procedure

Page $12 / 24$ 
defined by ASTM C 470 (2019). After 24 hours moulds were opened and specimens were kept for wet curing for 28 days. After the elapse of the curing time all the specimens were tested for the compressive strength, spilt tensile strength and flexural strength in standard fashion. The results obtained for the compressive, spilt tensile and flexural strength of concrete mixes with the binary and ternary blending of the proposed ingredients are listed in Table 6 . 
Hardened properties of SCC mixes with cementitious materials

\begin{tabular}{|c|c|c|c|c|c|}
\hline $\begin{array}{l}\text { Mix } \\
\text { ID }\end{array}$ & $\begin{array}{l}\text { Mix } \\
\text { description }\end{array}$ & $\begin{array}{l}\text { Mix } \\
\text { blends }\end{array}$ & $\begin{array}{l}\text { Compressive Strength } \\
\text { (MPa) }\end{array}$ & $\begin{array}{l}\text { Spilt Tensile Strength } \\
\text { (MPa) }\end{array}$ & $\begin{array}{l}\text { Flexural Strength } \\
\text { (MPa) }\end{array}$ \\
\hline M1 & PC & Controlled & 53.89 & 2.50 & 5.12 \\
\hline M2 & $5 \mathrm{FA}$ & Binary & 54.46 & 3.10 & 6.14 \\
\hline M3 & $10 \mathrm{FA}$ & Binary & 55.4 & 3.53 & 6.35 \\
\hline M4 & $15 \mathrm{FA}$ & Binary & 56.61 & 3.81 & 6.62 \\
\hline M5 & $20 \mathrm{FA}$ & Binary & 52.98 & 3.56 & 6.41 \\
\hline M6 & $25 \mathrm{FA}$ & Binary & 51.76 & 2.95 & 6.01 \\
\hline M7 & $30 \mathrm{FA}$ & Binary & 50.782 & 2.90 & 5.03 \\
\hline M8 & $5 \mathrm{SF}$ & Binary & 54.31 & 4.37 & 5.97 \\
\hline M9 & $10 \mathrm{SF}$ & Binary & 56.44 & 5.03 & 6.04 \\
\hline M10 & $15 \mathrm{SF}$ & Binary & 54.11 & 4.14 & 5.22 \\
\hline M11 & $20 \mathrm{SF}$ & Binary & 52.39 & 4.13 & 4.89 \\
\hline M12 & 5 SF 5 FA & Ternary & 57.13 & 4.80 & 5.49 \\
\hline M13 & 5 SF 10 FA & Ternary & 61.33 & 4.99 & 5.81 \\
\hline M14 & 5 SF 15 FA & Ternary & 62.73 & 5.25 & 6.18 \\
\hline M15 & 5 SF 20 FA & Ternary & 58.39 & 5.11 & 5.70 \\
\hline M16 & 5 SF 25 FA & Ternary & 54.32 & 5.07 & 5.49 \\
\hline M17 & 5 SF 30 FA & Ternary & 53.52 & 3.99 & 4.44 \\
\hline M18 & 10 SF 5 FA & Ternary & 56.43 & 5.12 & 6.24 \\
\hline M19 & 10 SF 10 FA & Ternary & 58.89 & 5.42 & 6.58 \\
\hline M20 & 10 SF 15 FA & Ternary & 63.39 & 5.49 & 6.70 \\
\hline M21 & 10 SF 20 FA & Ternary & 54.12 & 4.92 & 6.64 \\
\hline M22 & 10 SF 25 FA & Ternary & 49.97 & 4.35 & 5.42 \\
\hline M23 & 10 SF 30 FA & Ternary & 48.62 & 3.13 & 5.24 \\
\hline M24 & 15 SF 5 FA & Ternary & 59.62 & 3.36 & 5.39 \\
\hline M25 & 15 SF 10 FA & Ternary & 61.57 & 3.16 & 5.51 \\
\hline M26 & 15 SF 15 FA & Ternary & 58.21 & 2.80 & 6.19 \\
\hline M27 & 15 SF 20 FA & Ternary & 58.6 & 2.64 & 6.04 \\
\hline M28 & 15 SF 25 FA & Ternary & 54.12 & 2.50 & 5.32 \\
\hline M29 & 15 SF 30 FA & Ternary & 52.06 & 2.32 & 4.01 \\
\hline M30 & 20 SF 5 FA & Ternary & 54.55 & 3.94 & 5.83 \\
\hline M31 & 20 SF 10 FA & Ternary & 59.46 & 3.71 & 5.58 \\
\hline M32 & 20 SF 15 FA & Ternary & 60.58 & 3.65 & 5.66 \\
\hline M33 & 20 SF 20 FA & Ternary & 52.03 & 3.41 & 5.64 \\
\hline M34 & 20 SF 25 FA & Ternary & 51.13 & 3.30 & 5.41 \\
\hline
\end{tabular}




\begin{tabular}{|llllll|}
\hline $\begin{array}{l}\text { Mix } \\
\text { ID }\end{array}$ & $\begin{array}{l}\text { Mix } \\
\text { description }\end{array}$ & $\begin{array}{l}\text { Mix } \\
\text { blends }\end{array}$ & $\begin{array}{l}\text { Compressive Strength } \\
\text { (MPa) }\end{array}$ & $\begin{array}{l}\text { Spilt Tensile Strength } \\
\text { (MPa) }\end{array}$ & $\begin{array}{l}\text { Flexural Strength } \\
\text { (MPa) }\end{array}$ \\
\hline M35 & 20 SF 30 FA & Ternary & 45.04 & 2.98 & 4.91 \\
\hline
\end{tabular}

\subsubsection{Compressive Strength}

The cube specimens with standard size were used to determine the compressive strength of SCC mixes. Table 6 lists the compressive strength results of the mixes including controlled mix. The variations in compressive strength of developed concrete mixes with binary and ternary blends of FA and SF with respect to that of the control mixture are shown in Fig. 11 (a), (b) and (c). In this figure subplot (a) shows the variation of compressive strength due to fly ash and silica fume. Whereas subplots (b) and (c) gives details of the variation of compressive strength due to dosage of silica fume from $5-20 \%$. It is observed that the strength of concrete with the addition of cementitious materials is dependent on the type of cementitious materials. The optimum cement replacement level of various cementitious materials also varies. This is due to the compatibility of cementitious materials with the cement and also their fineness. The compressive strength of the control mix at 28 days curing was measured equal to $53.89 \mathrm{MPa}$. The binary use of PC + FA increased the compressive strength of SCC mixes with an increase in the percentage of FA up to $15 \%$. Whereas, above $15 \%$ replacement levels of FA, the compressive strength slightly decreased. In the case of PC + SF, the compressive strength was increased as the dosage of SF increased up to $10 \%$, for other replacement levels the reduction in compressive strength was observed. After a certain replacement level, the cementitious materials create the dilution effect thus causing the reduction in pozzolanic reaction and thus result in the decrease of the strength. Therefore, it is observed that the compressive strength of concrete deteriorates after $15 \%$ and $10 \%$ replacement of cement with FA and SF respectively. The increase in compressive strength is more pronounced when both the cementitious materials are added together in SCC. The performance of the ternary system is found to be better than the binary system. Since the additives with smaller surface area and pozzolanic reactivity cannot contribute to the improvement of the strength at a quicker pace. Hence it may be said that they are not able to improve the early strength of concrete. However, at later stages, the strength of concrete with pozzolanic/cementitious materials is higher even at 28 days curing, even surpluses the strength of normal concrete without cementitious materials. The observation is also in very good agreement with the report presented by (Mehta and Gjorv 1982) on the combined use of normal and high reactive additions such as fly ash and silica fume respectively owes maximum benefits in terms of strength and durability characteristics of concrete (Khatri et al. 1995). Also, many researchers demonstrated that combined use of SF and FA resulted in improvements in compressive strength (Khatri et al. 1995; Mehta and Gjorv 1982; Ozyıldırım and Halstead 1994). In the present research study, the SCC containing 10SF\&15FA and 20SF\&30FA exhibited the highest and lowest compressive strength being $63.39 \mathrm{MPa}$ and $45.04 \mathrm{MPa}$ respectively. The enhancement in compressive strength is about $18 \%$ of the controlled mix.

\subsubsection{Spilt tensile strength}

Test results of indirect cylinder spilt with an average of five standard size cylindrical specimens for each batch are listed in Table 6 and Fig. 12. A similar trend as in-case of the compressive strength is observed in spilt tensile strength of the concrete. The average 28 days splitting tensile strength of SCC without cementitious materials is $2.50 \mathrm{MPa}$. The splitting tensile strength increases with the increase in fly ash contents up to $15 \%$ of cement replacement. With increasing the amount of FA content over $15 \%$, the splitting tensile strength decreases. Similarly, an increase in splitting tensile strength is observed for SF-contained concrete up to $10 \%$ cement replacement and beyond the $10 \%$ strength is slightly decreased. Similarly, likewise compressive strength the performance of split tensile strength is better in the case of a ternary blended system than a binary blended system. Also, the maximum tensile strength of SCC was recorded for the ternary mix having 10SF\&15FA is $5.49 \mathrm{~N} / \mathrm{mm}^{2}$. The average increase of $119 \%$ in tensile was observed when compared to controlled SCC. While the mix $15 \%$ SF \& 30\%FA exhibits the minimum tensile strength of $2.32 \mathrm{~N} / \mathrm{mm}^{2}$. Analogous to compressive strength Fig. 12 shows the variation of tensile strength. It may further be observed from the Fig. 12 that there is a significant effect of cement replacement materials in SCC. It indicates that tensile strength becomes more than double with the ternary use of SF and FA.

\subsubsection{Flexural strength}

Table 6 lists the flexural strength results of prism specimens tested in this research investigation. Figure 13 shows the details of the average flexural strength of SCC in a similar fashion to compressive and tensile strength. From the Fig. 13, it can be observed that the addition of cementitious materials improves the flexural performance of SCC. The average flexural strength of controlled SCC is $5.12 \mathrm{Mpa}$. With the inclusion of FA in a binary system the flexural performance increases with an increase of FA dosage up to $15 \%$,

Page $15 / 24$ 
beyond $15 \%$ replacement level is slightly decreased. Similarly, the binary mixes having SF enhance the flexural strength of SCC. Similar to compressive and tensile strength, the maximum flexural strength was observed at $15 \%$ fly ash and $10 \%$ SF in binary SCC mixes. Ternary mixes with 10SF \& 15FA experienced the maximum flexural strength of 6.70MPa. The average increase in flexural strength of $15 \%$ was observed when compared to the concrete without mineral additives. Furthermore, it was observed from bar charts in Fig. 12 that the flexural strength of SCCs is in agreement with the standard values reported in literature i.e., $30 \%$ of their respective compressive strength.

\section{Conclusions}

Based on the analysis and discussions of the tests' results obtained from the laboratory investigations conducted in this research work, the following are conclusions.

1. Fresh properties of SCC depend upon mix proportions and these can be adjusted with the appropriate dosage of SP.

2. The fresh properties significantly depend upon the dosage of SP, fly ash, silica fume and combination of these cementitious materials.

3. The optimum dosage of SP to maintain the required $T_{50}$ values varies from $2-4.5 \%$.

4. The maximum $T_{50}$ time is observed as $5.2 \mathrm{sec}$ for mix $20 \mathrm{SF}$ at the SP dosage of $4.5 \%$, while the minimum $\mathrm{T}_{50}$ time was observed as $3.2 \mathrm{sec}$ for mix 10 SF\&30FA at SP dosage of $2.25 \%$.

5. The importance of the addition of SP is observed to be more in the case of mixes with increasing dosage of SF than the corresponding levels of FA, irrespective of the type of mix being binary or ternary.

6. An identical trend is observed in all other fresh properties (Slump flow diameter, V-funnel time, J-Ring height, L- box height ratio and V-funnel time at $5 \mathrm{~min}$ for all the mixes. Also, it is noted that the obtained values are within the limits specified by EFNARC for SCC dosages of SP optimized with $T_{50}$ tests.

7. The results of fresh properties conducted for all the 35 mixes developed remained within the specified range of EFNARC.

8. The compressive strength of SCC depends upon the dosage of cement replacement materials both at individual and combined levels.

9. In individual SCC mixes the compressive strength increases with an increase in the parentage of fly ash up to $15 \%$ and silica fume up to $10 \%$ and is equal to $5.05 \%$ and $4.73 \%$ of CM respectively.

10. The increase in compressive strength is more pronounced when both the cementitious materials are added combinedly in SCC.

11. The maximum compressive strength equal to $63.39 \mathrm{MPa}$ was observed at a dosage of $10 \%$ Silica fume and $15 \%$ Fly ash.

12. The increment in compressive strength is about $18 \%$ of $\mathrm{CM}$.

13. Splitting tensile strength and flexural strength of concrete in all the cases showed the identical trend as compressive strength. The maximum splitting tensile strength and flexural strength were recorded equal to $5.49 \mathrm{MPa}$ and $6.7 \mathrm{MPa}$ respectively in concrete having (10\% Silica fume \& $15 \%$ Fly ash).

14. The maximum increase in splitting tensile and flexural strength is $119 \%$ and $31 \%$ respectively when compared to the $\mathrm{CM}$.

15. The tensile strength and flexural strength of the entire mixes are in agreement with the standard values being $5-15 \%$ and $30 \%$ respectively, of its respective compressive strength.

On the basis of the above conclusion, the mix with 10\% SF and 15\% FA is selected as an optimized mix that yields compressive, spilt tensile and flexural strength $63.39 \mathrm{MPa}, 5.49 \mathrm{MPa}$ and $6.7 \mathrm{MPa}$ respectively, which are approximately $18 \%, 119 \%, 31 \%$ greater than the ordinary SCC without cementitious materials. 


\section{Declarations}

\section{Acknowledgement}

The authors would like to acknowledge the financial support provided by Quaid-e-Awam University of Engineering, Science \& Technology, Sindh, Pakistan.

\section{Conflicts of Interest}

The authors declare that they have no conflicts of interest.

\section{Data Availability}

The data used to support the findings of this study are available from the corresponding author upon request.

Declarations Ethics approval

This article does not contain any studies with human participants or animals performed by any of the authors.

\section{Consent to participate}

Not applicable.

\section{Consent for publication}

Not applicable

\section{Author contribution}

Muneeb Ayoub Memon: Investigation, Methodology, Experimental work, Original draft preparation

Noor Ahmed Memon: Supervision, Conceptualization, Writing-Reviewing and Editing.

Bashir Ahmed Memon: Writing-Reviewing and Editing, Conceptualization.

\section{Funding}

No funds, grants, or other support was received.

\section{References}

1. ASTM American Society for Testing Materials (2019) C 1240-15. Standard test method for silica fume used in cementitious mixtures. Society for Testing and Materials International, American

2. ASTM American Society for Testing Materials (2019) C 470. Standard test method for moulds for forming concrete tests. Society for Testing and Materials International, American

3. ASTM American Society for Testing Materials (2019) C 494. Standard test method for chemical admixtures for concrete. Society for Testing and Materials International, American

4. ASTM American Society for Testing Materials (2019) C 618-17. Standard test method for coal fly ash and raw or calcined natural pozzolan for use in concrete". Society for Testing and Materials International, American.

5. ASTM American Society for Testing Materials (2019) C150M-18. Standard test method for cement used in concrete.Society for Testing and Materials International, American

6. Bagheri A, Zanganeh H, Alizadeh H, Shakerinia M, Marian MAS (2013) Comparing the performance of fine fly ash and silica fume in enhancing the properties of concretes containing fly ash. Constr Build Mater 47:1402-1408

7. Barragán B, Zerbino R, Gettu R, Soriano M, De la Cruz C, Giaccio G, Bravo M (2004, September) Development and application of steel fibre reinforced self-compacting concrete. In 6th RILEM Symp. on Fibre-Reinforced Concretes (FRC)-BEFIB: 457-466 
8. Bayasi Z, Zeng J (1993) Properties of polypropylene fiber reinforced concrete. Mater J 90(6):605-610

9. Benaicha M, Roguiez X, Jalbaud O, Burtschell Y, Alaoui AH (2015) Influence of silica fume and viscosity modifying agent on the mechanical and rheological behavior of self compacting concrete. Constr Build Mater 84:103-110

10. Benli A, Karataş M, Bakir Y (2017) An experimental study of different curing regimes on the mechanical properties and sorptivity of self-compacting mortars with fly ash and silica fume. Constr Build Mater 144:552-562

11. Bhanja S, Sengupta B (2005) Influence of silica fume on the tensile strength of concrete. Cem Concr Res 35(4):743-747

12. Bigas JP, Pellerin B, Deschryver F, Massinari P, Plizzari G (2007) 153 Synthetic macro-fibers reinforced self compacting concrete for lightweight precast elements. A case study. In 5th International RILEM Symp. on Self-Compacting Concrete:1013-1018 RILEM Publications SARL

13. Borralleras $P$, Barragàn $B$, Gettu R (2007) 162 Comparison of durability parameters between conventional concrete, standard SCC and steel fibre reinforced SCC for construction of thin elements-Part 1: Durability tests. In 5th International RILEM Symp. on Self-Compacting Concrete:1079-1091 RILEM Publications SARL

14. Carlswärd J (2006) Shrinkage cracking of steel fibre reinforced self compacting concrete overlays :test methods and theoretical modelling: test methods and theoretical modelling (Doctoral dissertation, Luleå tekniska universitet)

15. Choudhary R, Gupta R, Nagar R (2020) Impact on fresh, mechanical, and microstructural properties of high strength selfcompacting concrete by marble cutting slurry waste, fly ash, and silica fume. Constr Build Mater 239:117888

16. Concrete S C (2005) The European guidelines for self-compacting concrete. BIBM, et al, 22

17. Dehwah HAF (2012) Mechanical properties of self-compacting concrete incorporating quarry dust powder, silica fume or fly ash. Constr Build Mater 26(1):547-551

18. Deo SV, Pofale AD (2015) Parametric study for replacement of sand by fly ash for better packing and internal curing. Open $\mathrm{J}$ Civil Eng 5(01):118

19. Dhonde HB, Mo YL, Hsu TT, Vogel J (2007) Fresh and hardened properties of self-consolidating fiber-reinforced concrete. ACl J 104(5):491

20. Di Prisco M, Mauri M Scola M (2006) A new design for stabilizing ground slopes. In Second International Fib Congress:CD-CD

21. Druta C (2003) Tensile strength and bonding characteristics of self-compacting concrete

22. EFNARC S (2002) Guidelines for self-compacting concrete. London, UK: Association House:32, 34

23. Felekoğlu B, Tosun K, Baradan B, Altun A, Uyulgan B (2006) The effect of fly ash and limestone fillers on the viscosity and compressive strength of self-compacting repair mortars. Cem Concr Res 36(9):1719-1726

24. Ferrara L, Meda A (2006) Relationships between fibre distribution, workability and the mechanical properties of SFRC applied to precast roof elements. Mater Struct 39(4):411-420

25. Gesoğlu M, Özbay E (2007) Effects of mineral admixtures on fresh and hardened properties of self-compacting concretes: binary, ternary and quaternary systems. Mater Struct 40(9):923-937

26. Gokulnath V, Ramesh B, Reddy SS (2020) Addition of reinforcing materials in self compacting concrete. Materials Today Proceedings 22:722-725

27. Groth P, Nemegeer D (1999) The use of steel fibres in self-compacting concrete. In Self-compacting concrete (Stockholm, 13-14 September 1999):497-507

28. Grunewald S (2004) Performance based design of self compacting steel fiber reinforced concrete. Department of Structural and Building Engineering

29. Güneyisi E, Gesoğlu M, Özbay E (2010) Strength and drying shrinkage properties of self-compacting concretes incorporating multi-system blended mineral admixtures. Constr Build Mater 24(10):1878-1887

30. Kapoor K, Singh SP, Singh B (2016) Durability of self-compacting concrete made with Recycled Concrete Aggregates and mineral admixtures. Constr Build Mater 128:67-76

31. Khatri RP, Sirivivatnanon V, Gross W (1995) Effect of different supplementary cementitious materials on mechanical properties of high performance concrete. Cem. Concr Res 25(1):209-220

32. Khayat K, Mitchell D (2009) Self-consolidating concrete for precast, prestressed concrete bridge elements (Vol. 628). Transportation Research Board 
33. Mardani-Aghabaglou A, Sezer Gi, Ramyar K (2014) Comparison of fly ash, silica fume and metakaolin from mechanical properties and durability performance of mortar mixtures view point. Constr Build Mater 70:17-25

34. Mastali M, Dalvand A (2016) Use of silica fume and recycled steel fibers in self-compacting concrete (SCC). Constr Build Mater 125:196-209

35. Mehta PK, Gjorv OE (1982) Properties of portland cement concrete containing fly ash and condensed silica-fume. Cem Concr Res 12(5):587-595

36. Mehta PK, Gjørv OE (1982) Properties of portland cement concrete containing fly ash and condensed silica-fume. Cem Concr Res 12(5):587-595

37. Memon MA, Memon NA, Memon BA (2020) Effect of Fly Ash and Un-crushed Coarse Aggregates on Characteristics of SCC. Civil Eng J 6(4):693-701

38. Memon NA, Memon MA, Lakho NA, Memon FA, Keerio MA, Memon AN (2018) A review on self compacting concrete with cementitious materials and fibers. Eng Tech \& Appl Scie Res 8(3):2969-2974

39. Mohamed HA (2011) Effect of fly ash and silica fume on compressive strength of self-compacting concrete under different curing conditions. Ain Shams Engineering Journal 2(2):79-86

40. Nochaiya T, Wongkeo W, and Chaipanich A (2010) Utilization of fly ash with silica fume and properties of Portland cement-fly ash-silica fume concrete. Fuel 89(3):768-774

41. Nocher M (2001) Flowing Smoothly and Quietly. Advanced Concrete and Masonry Center Concrete Quarterly Issue 198 UK

42. Ozyıldııı C, Halstead WJ (1994) Improved concrete quality with combinations of fly ash and silica fume. ACI Mater J 91(6):587-594

43. Ozyildirim C, Halstead WJ (1995) Improved concrete quality with combinations of fly ash and silica fume. In Fuel and Energy Abstracts 5(36):337

44. Pereira ENB, Barros JA, Ribeiro AF, Camões A (2004) Post-cracking behaviour of selfcompacting steel fibre reinforced concrete

45. Perssoiv B (1998) Technical Report Japan Society for the Promotion of Science. Report 9803: 12. Division of Building Materials, Lund Institute of Technology, Lund

46. Persson B (2001) A comparison between mechanical properties of self-compacting concrete and the corresponding properties of normal concrete. Cem Conc Res 31(2):193-198

47. Ponikiewski T, Gołaszewski J (2014) The effect of high-calcium fly ash on selected properties of self-compacting concrete. Archives of civil and mechanical engineering 14(3):455-465

48. Razak HA, Wong HS (2005) Strength estimation model for high-strength concrete incorporating metakaolin and silica fume. Cem Concr Res 35(4):688-695

49. Romano GQ, Silva FA, Toledo Filho RD, Fairbairn EMR, Battista RC (2007) 133 Mechanical characterization of steel fiber reinforced self-compacting refractory concrete. In 5th International RILEM Symp. on Self-Compacting Concrete :881-886. RILEM Publications SARL

50. Sasanipour H, Aslani F (2019) Effect of specimen shape, silica fume, and curing age on durability properties of self-compacting concrete incorporating coarse recycled concrete aggregates. Constr Build Mater 228:117054

51. Sasanipour H, Aslani F, Taherinezhad J (2019) Effect of silica fume on durability of self-compacting concrete made with waste recycled concrete aggregates. Constr Build Mater 227:116598

52. Silva PRD, Brito JD (2015) Fresh-state properties of self-compacting mortar and concrete with combined use of limestone filler and fly ash. Mater Res 18(5):1097-1108

53. Sonebi M (2004) Medium strength self-compacting concrete containing fly ash: Modelling using factorial experimental plans. Cem Conc Res 34(7):1199-1208

54. Thomas MD, Shehata MH, Shashiprakash SG, Hopkins DS, Cail K (1999) Use of ternary cementitious systems containing silica fume and fly ash in concrete. Cem Concr Res 29(8):1207-1214

55. Verian KP, Ashraf W, Cao Y (2018) Properties of recycled concrete aggregate and their influence in new concrete production. Resources, Conservation and Recycling, 133:30-49 
56. Vivek SS, Narayanan RS, Dhinakaran G (2017) Comparative study on flexural behaviour of RCC beam and SCC ternary beams with mineral admixtures. Constr Build Mater. 152:57-64

57. Wang Q, Yan P, Feng J (2012) The influence of mineral admixtures on bending strength of mortar on the premise of equal compressive strength J Wuhan University of Technology-Mater Sci Ed 27(3):586-589

58. Wongkeo W, Thongsanitgarn P, Ngamjarurojana A, Chaipanich A (2014) Compressive strength and chloride resistance of selfcompacting concrete containing high level fly ash and silica fume. Mater Des, 64:261-269

59. Yahia A, Tanimura M, Shimabukuro A, Shimovama Y (1999) Effect of rheological parameters on self-compactability of concrete containing various mineral admixtures". In Self-compacting concrete (Stockholm, 13-14 September 1999):523-535

60. Zhu Y, Ma B, Li X, Hu D (2013) Ultra high early strength self-compacting mortar based on sulfoaluminate cement and silica fume. J Wuhan University of Technology-Mater Sci Ed 28(5):973-979

\section{Figures}

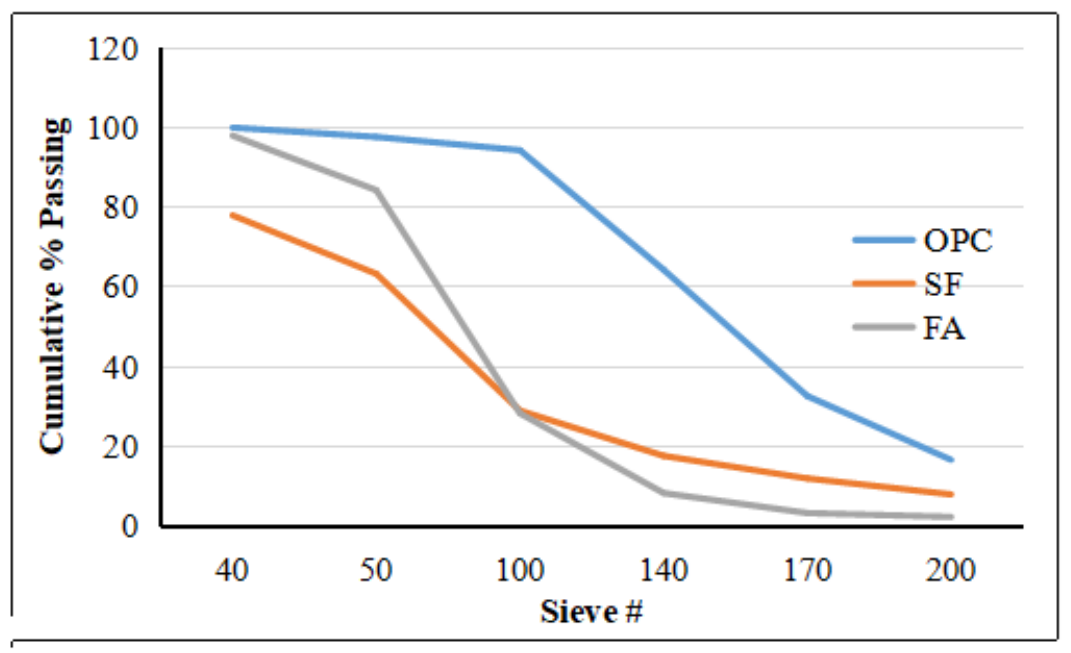

\section{Figure 1}

Gradation of Cement, Silica fume and Fly ash.
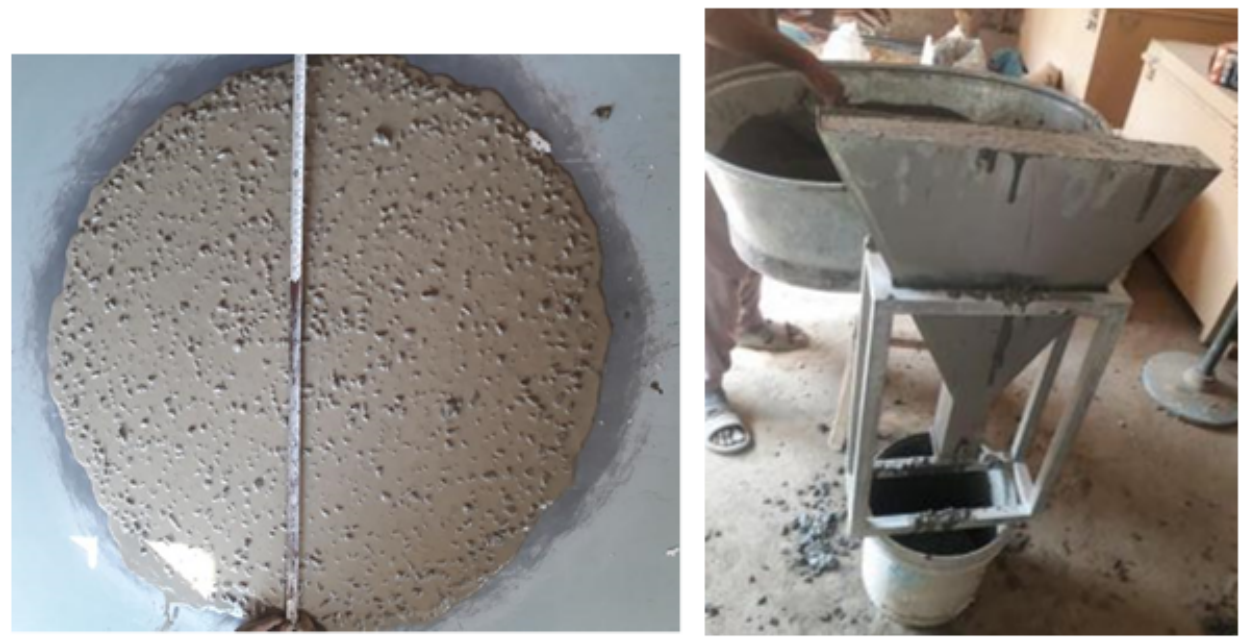

Figure 2 


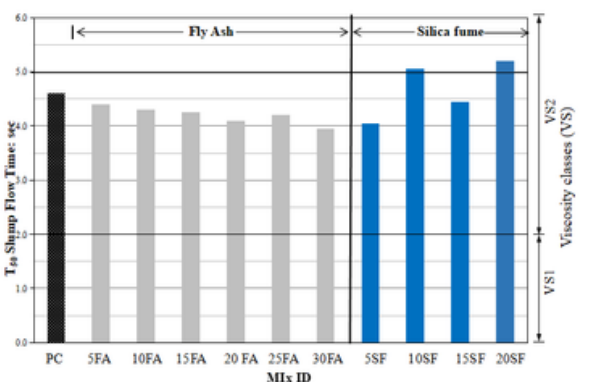

(a)

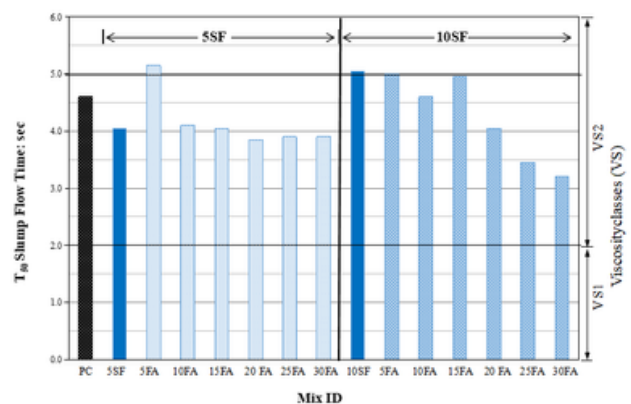

(b)

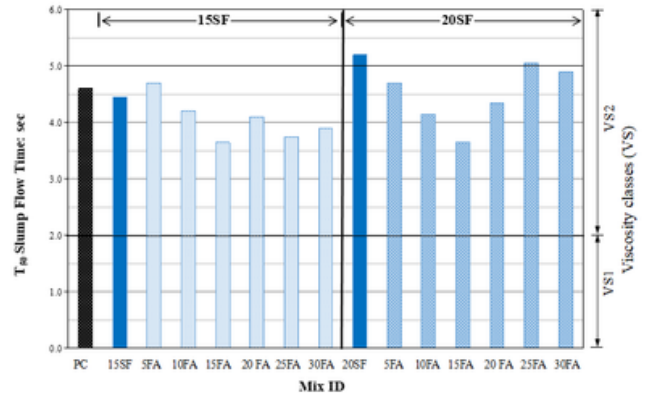

(c)

Figure 3

Variation of slump flow time and viscosity classes (a) individually FA and SF. (b) FA combined with $5 \%$ \& 10\% SF (c) FA combined with $15 \%$ \& $20 \%$ SF

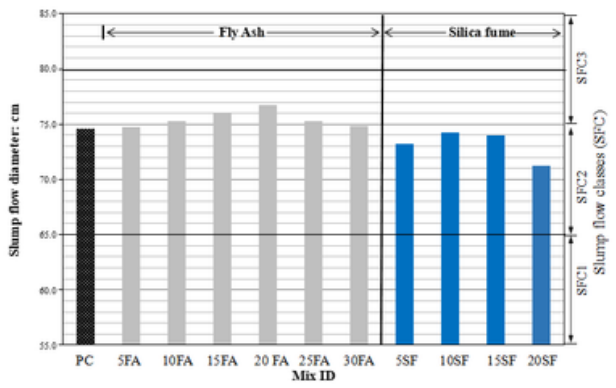

(a)

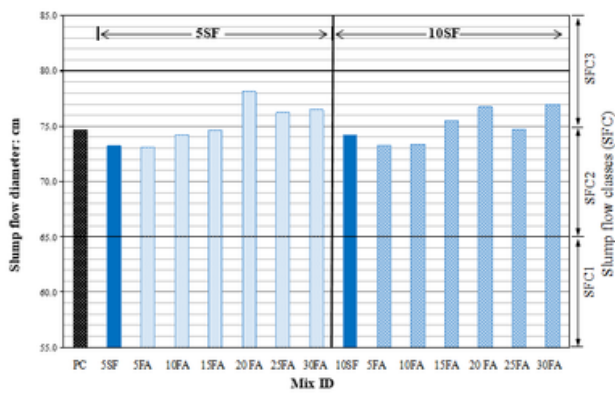

(b)

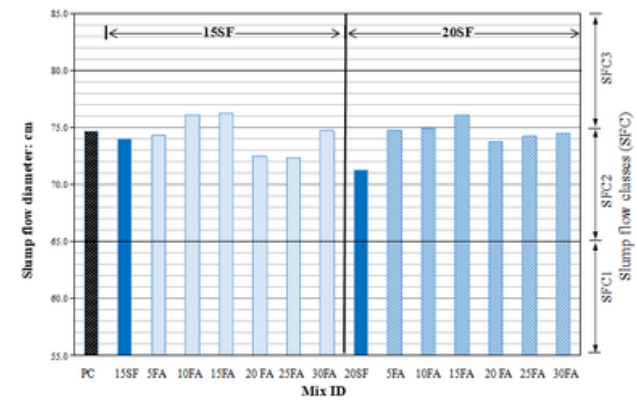

(c)

Figure 4

Variation of slump flow diameter and slump flow classes (a) individually FA. and SF (b) FA combined with 5\% \& $10 \%$ SF (c) FA combined with $15 \%$ \& $20 \%$ SF

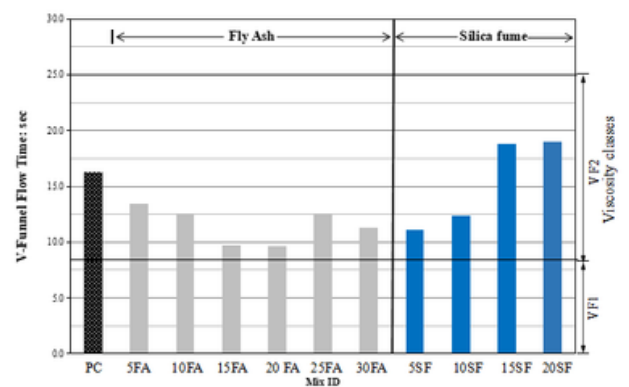

(a)

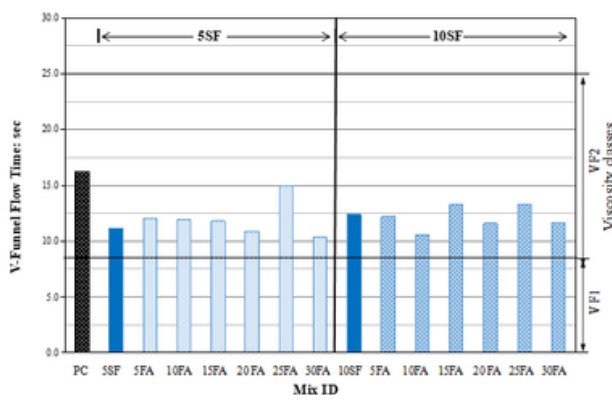

(b)

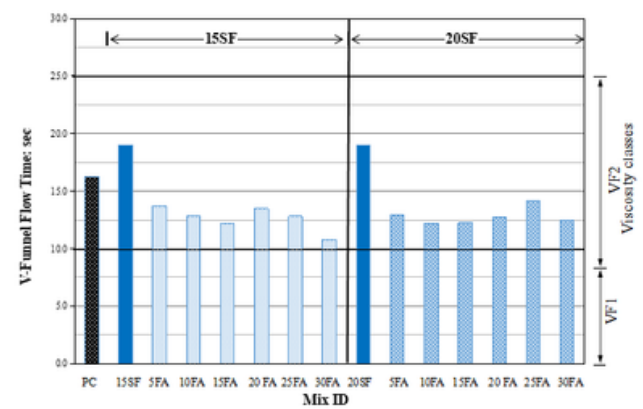

(c)

Figure 5

Variation of V-funnel flow time and Viscosity classes (a) individually FA and SF (b) FA combined with 5\% \& 10\% SF (c)FA combined with $15 \%$ \& $20 \%$. 


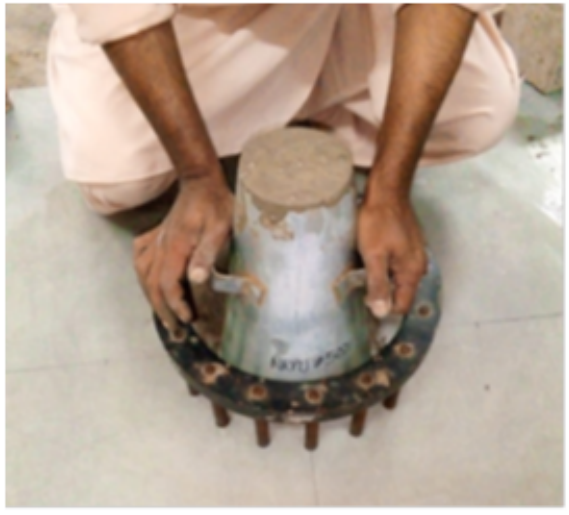

(a)

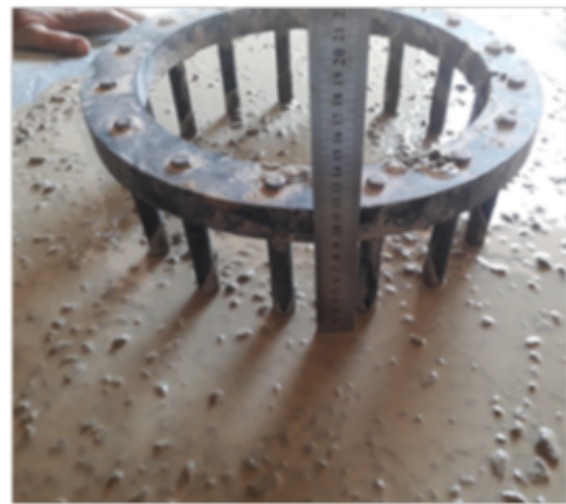

(b)

\section{Figure 6}

Pictorial view of Passing ability tests (a) J-ring test (b) J-ring height.

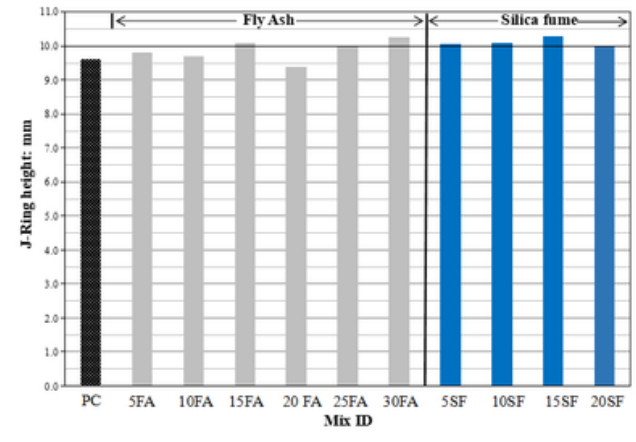

(a)

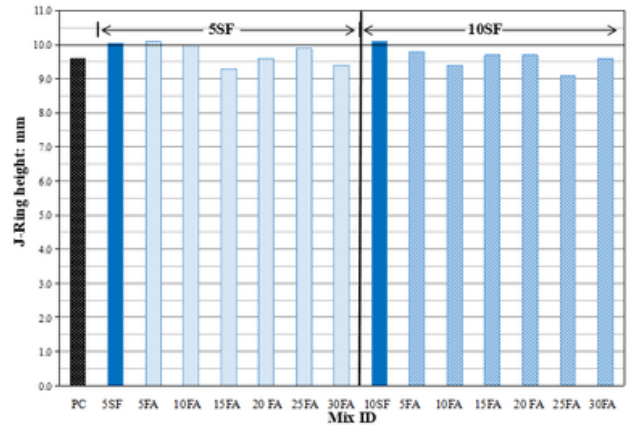

(b)

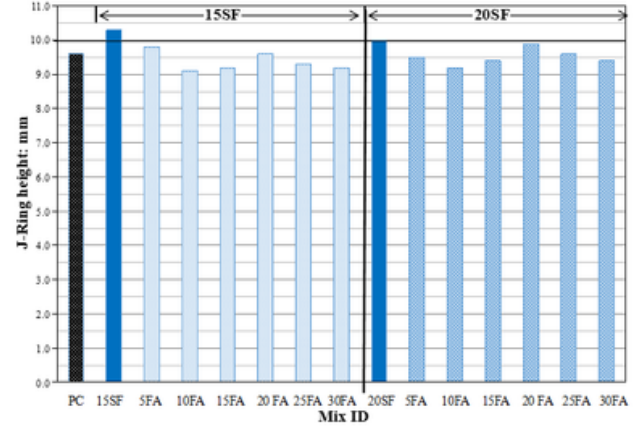

(c)

\section{Figure 7}

Variation of J-Ring height (a) individually FA and SF (b) FA combined with $5 \%$ \& 10\% SF (c) FA combined with $15 \%$ \& $20 \%$ SF.

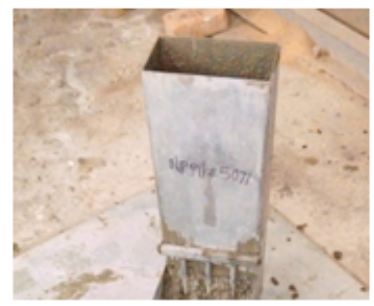


Figure 8

Pictorial view of flow concrete through L-box.

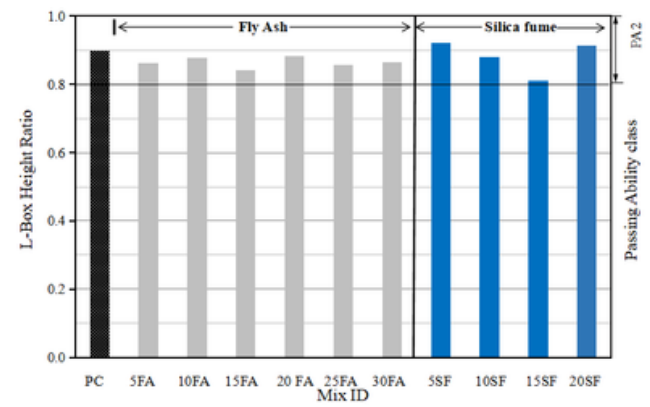

(a)

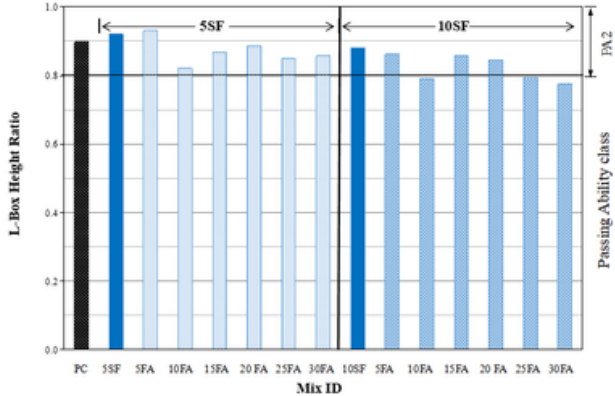

(b)

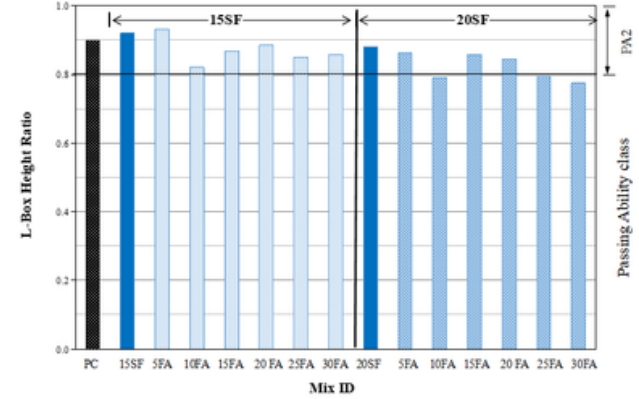

(c)

\section{Figure 9}

Variation of L-Box height ratio and Passing ability class (a) individually FA and SF (b) FA combined with $5 \%$ \& $10 \%$ SF (c) FA combined with FA combined with $15 \%$ \& $20 \%$ SF.

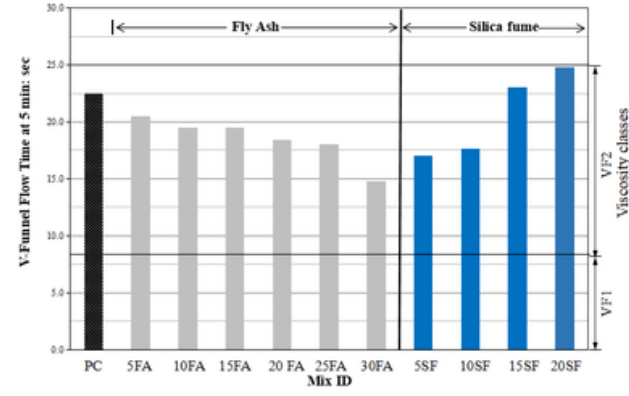

(a)

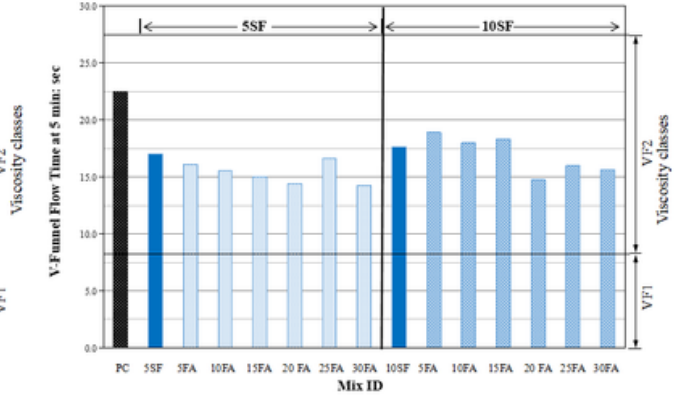

(b)

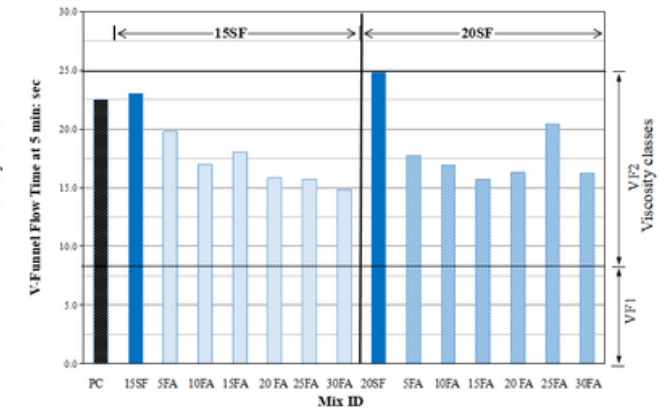

(c)

\section{Figure 10}

Variation of V-funnel flow time at 5 min and Viscosity classes (a) individually FA and SF (b) FA combined with 5\% \& 10\% SF (c) FA combined with $15 \%$ \& $20 \%$ SF.

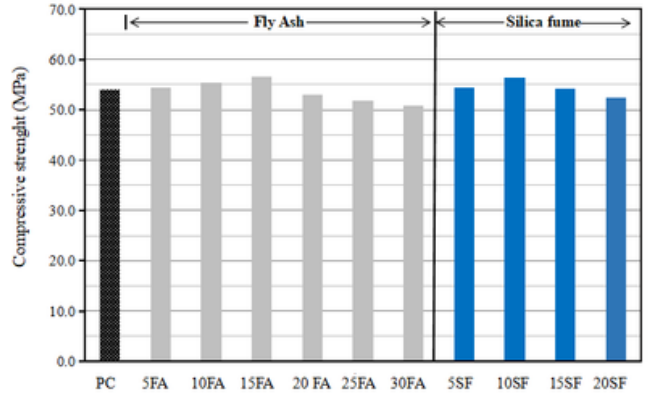

(a)

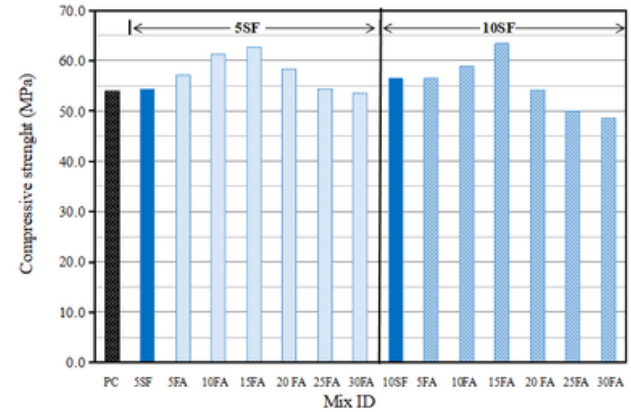

(b)

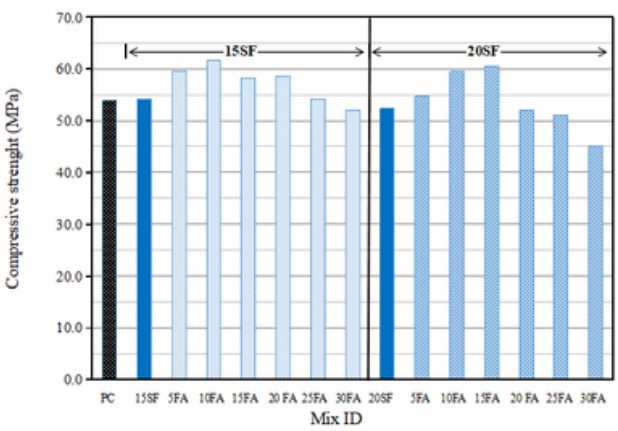

(c)

Figure 11 
Variation of Compressive Strength with (a) individually FA and SF (b) FA combined with $5 \%$ \& $10 \%$ SF (c) FA combined with $15 \%$ \& $20 \%$ SF.

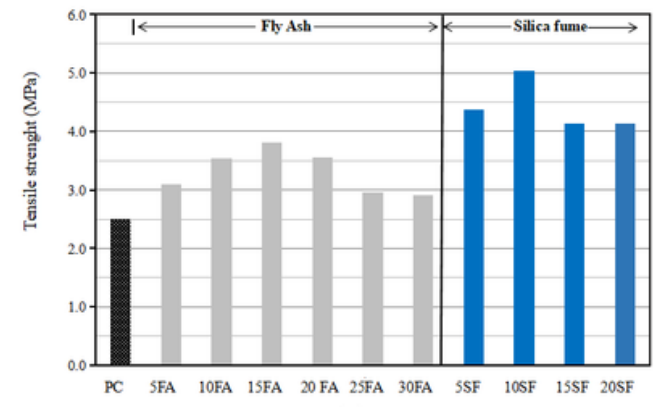

(a)

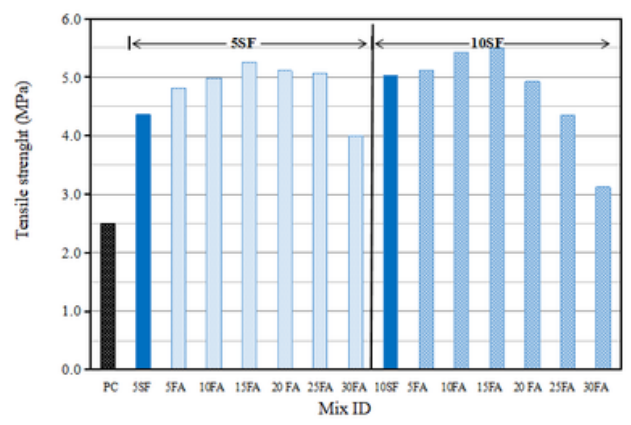

(b)

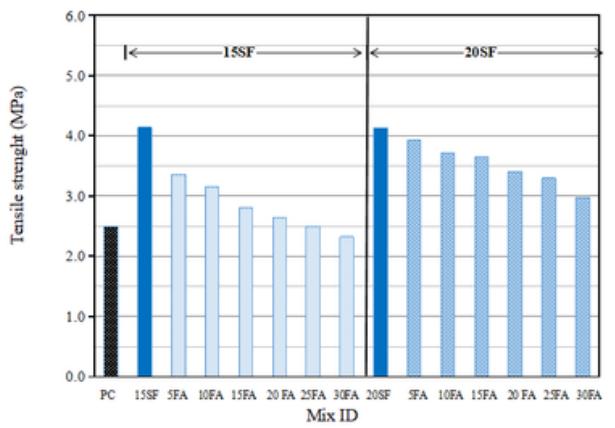

(c)

\section{Figure 12}

Variation of Spilt tensile strength with (a) individually FA and SF (b) FA combined with $5 \%$ \& $10 \%$ SF (c) FA combined with $15 \%$ \& $20 \%$ SF

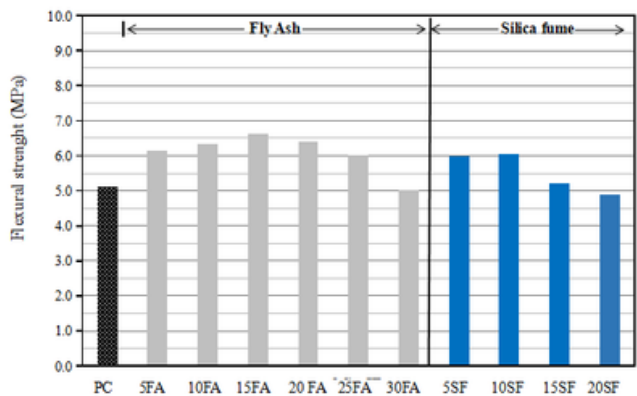

(a)

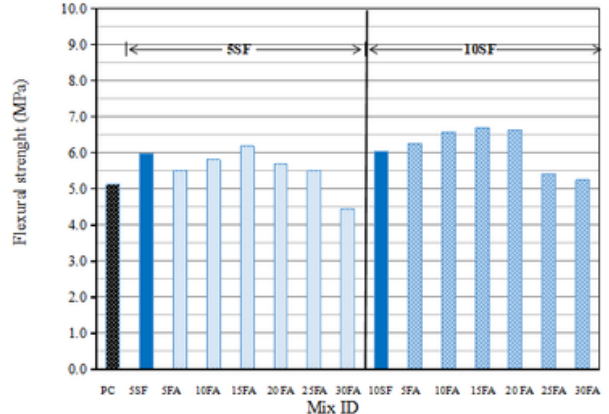

(b)

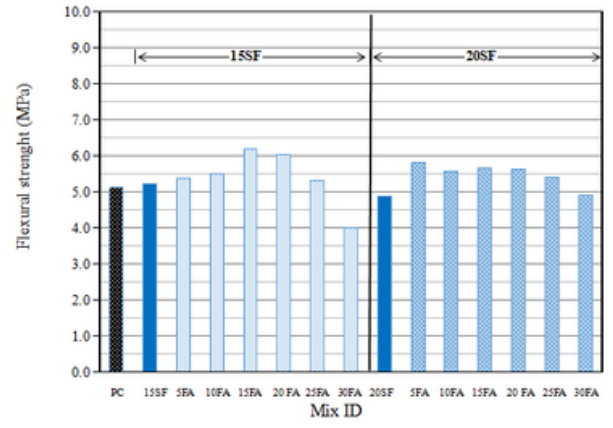

(c)

\section{Figure 13}

Variation of Flexural strength with (a) individually FA and SF (b) FA combined with $5 \%$ \& $10 \%$ SF (c) FA combined with $15 \%$ \& $20 \%$ SF. 